Historic, archived document

Do not assume content reflects current scientific knowledge, policies, or practices. 



\title{
THE DISTRIBUTION OF THE BOLL WEEVIL IN 1919
}

\author{
By B. R. COAD
}

The most important development of the year 1919 with regard to the movement of the weevil is the very rapid advance northward along the eastern portion of the line in the States of Tennessee, Georgia, South Carolina, and North Carolina. West of the Mississippi River there was comparatively little change from the 1918 line. A slight recession was noted entirely across Arkansas. The only important change in Oklahoma was the regaining of a few counties in the central portion of the State. In Texas the line shows a slight gain in the northern portion of the State while there is a corresponding loss in the southern portion. These two shifts so nearly balance each other that a net loss of only 250 square miles is shown for the State of Texas. East of the Mississippi River the changes are vastly more pronounced. In the western half of Tennessee the line shows only a slight gain over that of 1918. Moving eastward, however, this gain increases rapidly and the line extends up the Tennessee River Valley to practically the limit of cotton cultivation in that vicinity. This places the entire State of Alabama well within the line. In Georgia the line advances practically to the limit of cotton cultivation and it does the same in. South Carolina. North Carolina is infested for the first time and seven counties in the southern end of the State are wholly or partially included.

In Texas the line passes from western Val Verde County to Mertzon in Irion County, then runs eastward through the southern portions of Tom Green and Concho Counties to Brady in McCulloch County, thence northward through Bangs in Brown County to Baird in Callahan County, through the eastern part of Shackelford County to Spring Creek in Throckmorton County and across Archer County to Iowa Park in Wichita County, and reaches the border on the Red River by crossing the northern end of Clay County.

In Oklahoma the line enters the State just south of Waurika in Jefferson County, runs northward through Stephens County to Naples in Grady County, and crosses the northern corner of McClain and Cleveland Counties to Edmond in Oklahoma County. It then turns southeast through Lydelotte in Pottawatomie County, extends across Seminole County to Yeager in Hughes County and to Kiowa in Pittsburg County, thence through Latimer County to Heavener in Le Flore County.

In Arkansas the line passes through Waldron in Scott County, northeastward across Logan County to Cabin Creek in Johnson County, extends through Pope County to Clinton in Van Buren County, then declines southeastward through Cleburne, White, and Woodruff Counties to Forest City in St. Francis County, then northeastward through Harvard in Crittenden County.

In Tennessee the line passes through Millington in Shelby County, Taylors Chapel in Fayette County, Teague in Hardeman County, and north of Henderson in Chester County; thence southeastward along the north edge of Hardin and across Wayne and Lawrence Counties to Pulaski in Giles County; then to Elora in Lincoln County and Sherwood in Franklin County. It extends through Marion County and advances sharply just north of Chattanooga in Hamilton County and runs northeastward to Evensville in Rhea County, crosses the northern portions of Meigs and McMinn Counties to Madisonville in Monroe County and then turns southwestward through Polk County, leaving the State near Tennga.

In Georgia the line runs southeastward from Tennga through Murray and Gilmer Counties to Jasper in Pickens County, then across Dawson County to Gainesville in Hall County and to Homer in Banks County, thence through Franklin County to Hartwell in Hart County.

In South Carolina the line passes through Anderson in Anderson County to Laurens in Laurens County, crosses the southern end of Union County, runs through Cornwell in Chester County and Pleasant Hill in Lancaster County, then extends to Chesterfield in Chesterfield County and across the northern end of Marlboro County, leaving the State just north of McColl.

In North Carolina the line enters the extreme southeastern corner of Scotland County, then runs southeastward across Robeson County through Barnesville, across Columbus County through Whiteville, and crosses the southern portion of Bladen County to Rocky Point and Scotts Hill in Pender County.

In Florida the line runs through Ozona in Pinellas County, Tampa, Seffner, and Plant City in Hillsborough County, Fort Meade in Polk County, Kissimmee in Osceola County, and Indian River City in Brevard County.

The weevil as recorded for 1918 in Eddy County, New Mexico, evidently failed to become eatablished under the adverse conditions prevailing in that district, and no specimen was located there during 1919.

The weevil also occurs in the mountains of Arizona, in Cochise, Santa Cruz, and Pima Counties on a wild cotton plant (Thurberia thespesioides), but has not yet attacked cotton in that State. It has not been found in California.

Altogether, the weevil invaded 40,150 square miles of new territory during 1919 and lost 5,650 square miles of territory which was infested during 1918, thus showing a net gain of 34,500 square miles in 1919 . About 115,000 square miles of cotton territory still remain uninfested.

Table I shows the gains and losses in territory during 1919 by States;

TABLE I.-Total area in square miles infested by the boll weevil in 1919.

\begin{tabular}{|c|c|c|c|c|c|}
\hline State. & $\begin{array}{c}\text { Year } \\
\text { first } \\
\text { infested. }\end{array}$ & $\begin{array}{c}\text { Area } \\
\text { infested } \\
\text { in } 1918 .\end{array}$ & $\begin{array}{c}\text { Gain in } \\
1919 .\end{array}$ & $\begin{array}{c}\text { Loss in } \\
1919 .\end{array}$ & $\begin{array}{c}\text { Area } \\
\text { infested } \\
\text { in } 1919 .\end{array}$ \\
\hline 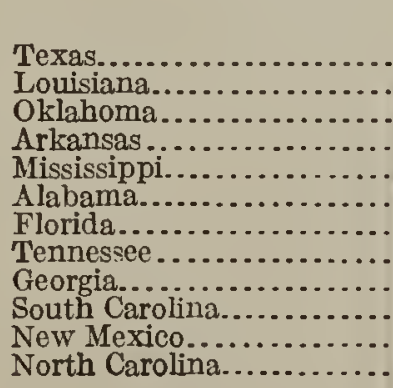 & $\begin{array}{l}1892 \\
1903 \\
1906 \\
1906 \\
1907 \\
1910 \\
1911 \\
1914 \\
1915 \\
1917 \\
1918 \\
1919\end{array}$ & $\begin{array}{r}\text { Sq. miles. } \\
174,500 \\
40,800 \\
16,800 \\
39,000 \\
46,340 \\
49,900 \\
35,000 \\
3,500 \\
46,300 \\
5,500 \\
100 \\
0\end{array}$ & 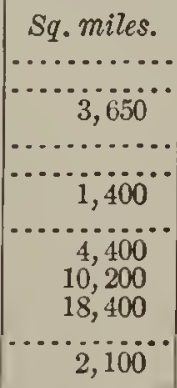 & 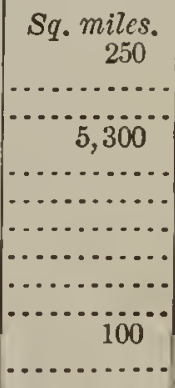 & $\begin{array}{r}\text { Sq. miles. } \\
174,250 \\
40,800 \\
20,450 \\
33,700 \\
46,340 \\
51,300 \\
35,000 \\
7,900 \\
56,500 \\
23,900 \\
0 \\
2,100\end{array}$ \\
\hline Total.. & & 457,740 & 40,150 & 5,650 & 492,210 \\
\hline
\end{tabular}


In order to give a comprehensive idea of the importance from the cotton-producing standpoint of the various districts still free from boll weevil infestation. Table II has been prepared. This summarizes the distribution of cotton production throughout the United States for the 10-year period of 1909 to 1918, inclusive, and distributes this production within each State between the infested and uninfested areas, as shown by the 1919 dispersion line.

TABLE II.-Proportion of cotton crop produced by States in area now free from u'eevil.

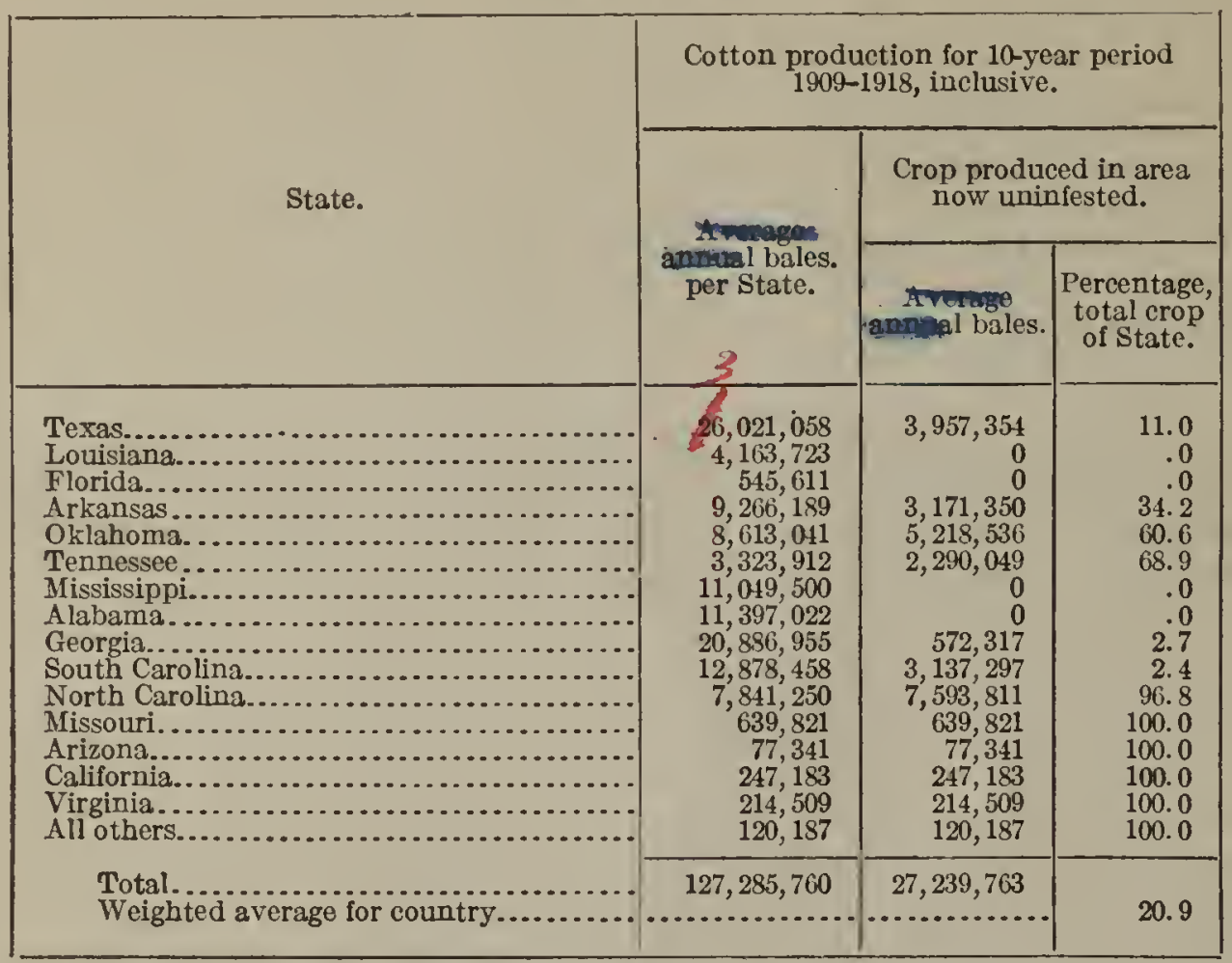

From Table II it is seen that only 11 per cent of the Texas crop is produced outside the weevil line. In Oklahoma 60 per cent is produced beyond the weevil-infested area and in Arkansas and Tennessee the percentages are 34 and 68, respectively. Georgia and South Carolina each produce only abol't 2 per cent of their crop beyond the weevil line, thus showing practically complete infestation, while the district which has been infested in North Carolina so far produces only about 3 per cent of the crop in that State. Considering the United States as a whole, it is seen that a general average of 20.9 per cent of the total cotton crop is produced in uninfested territory. This gives some idea of the importance of the territory which is still possibly subject to weevil infestation.

We are indebted to Prof. Franklin Sherman and assistants, of the North Carolina Department of Agriculture; Prof. A. F. Conradi and Mr. J. A. Berly, of the South Carolina Agricultural Experiment Station; and Mr. A. C. Lewis and assistants, of the Georgia State Board of Entomology, for assistance in determining the advance of the weevil. The bulk of the work was done by the following agents: E. S. Tucker, R. W. Moreland, T. F. McGehee, and F. F. Bondy. 